\title{
Wypadek w drodze do pracy lub z pracy a wypadek przy pracy na gruncie prawa pracy i ubezpieczeń społecznych
}

\section{Ewolucja regulacji prawnej}

Pierwotnie wypadek podczas wykonywania pracy i odbywania drogi do pracy był tak samo kwalifikowany jako wypadek w zatrudnieniu. Rozróżnienie tych dwóch okoliczności zostało wprowadzone ustawą z 23 stycznia 1968 r. o świadczeniach pieniężnych przysługujących w razie wypadków przy pracy ${ }^{2}$, kiedy to wypadek podczas wykonywania pracy w uspołecznionych zakładach pracy był traktowany jako wypadek przy pracy, a wypadek podczas wykonywania pracy w nieuspołecznionych zakładach pracy i odbywanie drogi do pracy podlegało pod wypadek w zatrudnieniu. Tzw. wypadkom w zatrudnieniu, zgodnie z cytowaną ustawą, ulegali pracownicy nieuspołecznionych zakładów pracy w takich samych okolicznościach, w jakich pracownicy uspołecznionych zakładów pracy ulegali wypadkom przy pracy, a także pracownicy obu rodzajów zakładów pracy w czasie odbywania drogi do pracy lub z pracy ${ }^{3}$.

Ustawa z dnia 12 czerwca 1975 r. o świadczeniach z tytułu wypadków przy pracy i chorób zawodowych ${ }^{4}$ nie dokonywała już rozróżnienia na uspołecznione i nieuspołecznione zakłady pracy. Na mocy tej ustawy został wprowadzony podział na wypadek przy pracy i wypadek w drodze do pracy, niemniej jednak ochrona w obu tych przypadkach była taka sama. Odrębne ubezpieczenie wypadkowe zostało wprowadzone ustawą z dnia 13 października 1998 r. o systemie ubezpieczeń społecznych ${ }^{5}$, natomiast wypadek w drodze do pracy i z pracy nadal regulowała ustawa o świadczeniach pieniężnych z ubezpieczenia społecznego w razie choroby i macierzyństwa.

Na gruncie obowiązujących przepisów prawa pracy i ubezpieczeń społecznych wypadek w drodze do pracy lub z pracy oraz wypadek przy pracy traktowane są jako dwa różne zdarzenia i podlegają pod dwa odrębne akty prawne. Pierwszy z nich normuje ustawa z dnia 25 czerwca 1999 r. o świadczeniach pieniężnych z ubezpieczenia społecznego w razie choroby i macierzyństwa ${ }^{6}$,

\footnotetext{
${ }^{1}$ Doktorantka, Uniwersytet Łódzki, Wydział Prawa i Administracji, Katedra Prawa Pracy.

${ }^{2}$ Dz.U. z 1968 r. Nr 3, poz. 8 ze zm.

${ }^{3}$ I. Jędrasik-Jankowska, Pojęcia i konstrukcje prawne ubezpieczenia społecznego, Warszawa 2016, s. 305.

${ }^{4}$ Tekst jedn. Dz.U. z 1983 r. Nr 30, poz. 144.

${ }^{5}$ Tekst jedn. Dz.U. z 2015 r. poz. 121.

${ }^{6}$ Tekst jedn. Dz.U. z 2014 r. poz. 159, dalej jako: u.ś.p.u.s.
} 
natomiast wypadek przy pracy regulowany jest ustawą z dnia 30 października 2002 r. o ubezpieczeniu społecznym z tytułu wypadków przy pracy i chorób zawodowych ${ }^{7}$.

\section{Pojęcie wypadku w drodze do pracy i z pracy oraz wypadku przy pracy}

Cechy wypadku przy pracy odróżniają ten wypadek od wypadku w drodze do pracy lub z pracy. Biorąc pod uwagę powiązania z pracą, oba te zdarzenia spełniają kryteria, natomiast samo określenie „wypadek przy pracy” odnosi się bezpośrednio do miejsca i czasu, w jakim daną pracę się wykonuje, a nie wiąże się z czasem na dojazd do niej i powrót z niej.

Przepis art. 3 ust. 5 u.ś.p.u.s. reguluje definicję wypadku w drodze do pracy lub z pracy. Zgodnie z nią, jest to zdarzenie nagłe, wywołane przyczyną zewnętrzną, które nastąpiło $\mathrm{w}$ drodze do lub z miejsca wykonywania pracy. O nagłości zdarzenia można mówić, gdy zdarzenie to wystąpi w czasie pokonywania drogi do lub z pracy ubezpieczonego. Jeżeli wypadek jest następstwem działania czynników zewnętrznych, a nie wewnętrznych, to możemy przyjąć, że występuje przyczyna zewnętrzna. Nie jest jednak istotny związek przyczyny z drogą, gdyż może to być jakakolwiek przyczyna zewnętrzna, np. napad na pracownika lub uderzenie pioruna. $\mathrm{W}$ związku miejscowym i czasowym przyczyna zewnętrzna powinna pozostawać jednak z drogą do pracy lub z pra$\mathrm{cy}^{8}$. Wyrok Sądu Apelacyjnego z dnia 26 czerwca 1997 r. rozwiewa wątpliwości czym jest wypadek $\mathrm{w}$ drodze do pracy. Zgodnie $\mathrm{z}$ tym orzeczeniem, droga ta $\mathrm{z}$ domu do pracy nie powinna zostać przerwana, a jeżeli nawet została przerwana, to przerwa musi być życiowo uzasadniona i jej czas nie może przekraczać granic potrzeby. Ocena, czy przerwa jest życiowo uzasadniona, powinna być dokonywana w aspekcie niezbędnych potrzeb bytowych pracownika, do jakich nie można zaliczyć podejmowania dodatkowego zatrudnienia. Skład sędziowski Sądu Apelacyjnego w wyroku z 13 kwietnia 2000 r. stwierdził, że robienie zakupów w drodze z pracy do domu jest czynnością życiowo uzasadnioną, zwłaszcza, gdy sklep ten znajduje się między pracą a domem9 Z kolei Sąd Najwyższy w orzeczeniu z dnia 25 stycznia 1980 r. orzekł, że drogą do pracy jest również droga powtórnie odbywana w tym samym dniu przez pracownika $\mathrm{z}$ domu do pracy, po załatwieniu sprawy osobistej, jeśli w tym celu uzyskał on czasowe zwolnienie od pracy. Pracownik rozpoczyna drogę do pracy po przekroczeniu progu swego mieszkania, co w przypadku zamieszkiwania w budynku jednomieszkaniowym oznacza przekroczenie progu domu ${ }^{10}$.

\footnotetext{
${ }^{7}$ Tekst jedn. Dz.U. z 2015 r. poz. 1242, dalej jako: u.u.s.w.p.

${ }^{8}$ M. Abramowski, Postepowanie powypadkowe, Warszawa 2010, s. 152-153.

${ }^{9}$ Wyrok SA w Warszawie z dnia 13 kwietnia 2000 r., III AUa 1142/99, OSA 2001/3/10.

${ }^{10}$ Wyrok Sądu Najwyższego z dnia 25 stycznia 1980 r., III URN 59/79, OSNC 1980/7-8/147.
} 
Zgodnie z art. 3 ust. 1 u.u.s.w.p., za wypadek przy pracy uważa się nagłe zdarzenie wywołane przyczyną zewnętrzną powodujące uraz lub śmierć, które nastąpiło $\mathrm{w}$ związku z pracą:

1) podczas lub w związku z wykonywaniem przez pracownika zwykłych czynności lub poleceń przełożonych;

2) podczas lub w związku $\mathrm{z}$ wykonywaniem przez pracownika czynności na rzecz pracodawcy, nawet bez polecenia;

3) w czasie pozostawania pracownika $w$ dyspozycji pracodawcy w drodze między siedzibą pracodawcy a miejscem wykonywania obowiązku wynikającego ze stosunku pracy.

Nagłe zdarzenie jest to zdarzenie gwałtowne i niespodziewane ${ }^{11}$. W wyroku Trybunału Ubezpieczeń Społecznych z dnia 19 września 1958 r. zostało rozszerzone pojęcie nagłości. Zgodnie z tym wyrokiem, działanie przyczyny zewnętrznej przez okres jednego dnia pracy nie odbiera zdarzeniu cechy nagłości ${ }^{12}$. Sąd Najwyższy w wyroku z dnia 4 października 2006 r. orzekł, że do uznania zdarzenia za wypadek przy pracy nie jest wymagane, żeby wystąpiła jednocześnie przyczyna i skutek. Nagłość to czas trwania zdarzenia ${ }^{13}$. Przyczyna zewnętrzna jest to przyczyna, która leży poza organizmem pracownika ${ }^{14}$. Przyczyną zewnętrzną jest zdarzenie, które nie jest powiązane z tym co się dzieje w organizmie pracownika, lecz jest to nagłe zdarzenie, które nie jest zależne od samego pracownika i jego ewentualnej choroby. W uchwale z dnia 11 lutego 1963 r. Sąd Najwyższy stwierdził, że przyczyną zewnętrzną może być każdy czynnik zewnętrzny, który wywoła w istniejących warunkach szkodliwe skutki na pracowniku ${ }^{15}$.

„Związek z pracą” oznacza miejscowe i czasowe lub funkcjonalne powiązanie zdarzenia z wykonywaniem ubezpieczonej czynności (pracy) ${ }^{16}$. Czasem pracy jest czas ściśle ustalony między pracownikiem a pracodawcą, jednak Sąd Najwyższy w wyroku z dnia 23 października 1980 r. stwierdził, że nie odbiera zdarzeniu charakteru wypadku przy pracy fakt, że zdarzenie miało miejsce po normalnych godzinach pracy poszkodowanego pracownika, o ile w tym czasie wykonywał on czynności $\mathrm{w}$ interesie zakładu pracy ${ }^{17}$. Samo stawienie się do pracy, czyli fizyczne przebywanie w zakładzie pracy, nie wyczerpuje treści obowiązku świadczenia pracy, w sytuacji, gdy pracownik nie jest przygotowany

\footnotetext{
${ }^{11}$ I. Jędrasik-Jankowska, op. cit., s. 322.

${ }^{12}$ Wyrok Trybunału Ubezpieczeń Społecznych z dnia 19 września 1958 r., TR III 149/1958, OSPiKA 1960, poz. 64.

${ }^{13}$ Wyrok Sądu Najwyższego z dnia 4 października 2006 r., II UK 40/06, OSNP 2007/19-20/291.

${ }^{14} \mathrm{M}$. Jachimowicz, Wypadki przy pracy $i$ choroby zawodowe. Świadczenia ubezpieczeniowe $i$ cywilne, Warszawa 2013, s. 21.

${ }^{15}$ Uchwała Sądu Najwyższego z dnia 11 lutego 1963 r., III PO 15/62, OSNC 1963/10/215.

${ }^{16}$ I. Jędrasik-Jankowska, op. cit., s. 331.

${ }^{17}$ Wyrok Sądu Najwyższego z dnia 23 października 1980 r., III PRN 43/80, Lex nr 14558.
} 
do jej wykonywania. Pozostawanie pracownika w gotowości do świadczenia pracy może być rozumiane jako świadczenie pracy, natomiast fizyczna obecność w zakładzie pracy, samo przebywanie w nim, nie wyczerpuje przesłanek świadczenia pracy ${ }^{18}$. Z kolei w wyroku z dnia 31 stycznia 1973 r. Sąd Najwyższy uznał, że pracownik, który uległ wypadkowi w czasie urlopu wypoczynkowego nie jest pozbawiony prawa do świadczeń z ustawy wypadkowej w sytuacji, gdy wykonywał on pracę w prawdzie bez polecenia, ale w interesie zakładu pracy ${ }^{19}$.

$\mathrm{Na}$ równi z wypadkiem przy pracy, biorąc pod uwagę zakres uprawnień do świadczeń z u.u.s.w.p., traktowany jest wypadek, któremu pracownik uległ:

1) w czasie podróży służbowej,

2) podczas szkolenia w zakresie powszechnej samoobrony,

3) przy wykonywaniu zadań zleconych przez działające u pracodawcy organizacje związkowe.

Śmiertelnym wypadkiem przy pracy jest wypadek, w wyniku którego nastąpiła śmierć w okresie do 6 miesięcy od dnia wypadku.

Art. 3 ust. 5 u.u.s.w.p. reguluje definicję ciężkiego wypadku przy pracy. Takim wypadkiem jest wypadek, w wyniku którego nastąpiło ciężkie uszkodzenie ciała, utrata wzroku, słuchu, mowy, zdolności rozrodczej lub inne uszkodzenie ciała lub rozstrój zdrowia, naruszające podstawowe funkcje organizmu, jak również choroba nieuleczalna lub zagrażająca życiu, trwała choroba psychiczna, całkowita lub częściowa niezdolność do pracy w zawodzie albo trwałe istotne zeszpecenie lub zniekształcenie ciała. Przesłanki te, zgodnie z cytowanym artykułem, zaliczają się do ciężkiego wypadku przy pracy. Jeżeli w wyniku tego samego zdarzenia wypadkowi uległy co najmniej dwie osoby, taki wypadek przy pracy uważa się za wypadek zbiorowy.

Wspólnym mianownikiem wypadku przy pracy oraz wypadku w drodze do pracy lub z pracy jest to, że oba te zdarzenia muszą posiadać cechę zdarzenia nagłego i być wywołane przyczyną zewnętrzną. Różnią się one zaś czasem i miejscem w jakim wypadki te występują.

\section{3. Świadczenia powypadkowe}

Świadczenia kompensacyjne w przypadku wypadku w drodze do pracy lub z pracy wypłacane są z ubezpieczenia chorobowego, po wykorzystaniu okresu wynagrodzenia za pracę za czas nieusprawiedliwionej nieobecności, natomiast świadczenia kompensacyjne w sytuacji, gdy ubezpieczony ulega wypadkowi przy pracy, wypłacane są z ubezpieczenia wypadkowego. Celem ubezpieczenia chorobowego jest ochrona „ubezpieczonego przed skutkami niezdolności

\footnotetext{
${ }^{18}$ Wyrok Sądu Najwyższego z dnia 7 marca 2006 r., I UK 127/05, Lex nr 299138.

${ }^{19}$ Wyrok Sądu Najwyższego z dnia 31 stycznia 1973 r., III URN 38/72, OSP 1973/7-8/143.
} 
do pracy z powodu zdarzeń losowych" ${ }^{20}$. Zgodnie z art. 2 u.ś.p.u.s., ubezpieczenie chorobowe obejmuje: zasiłek chorobowy, świadczenie rehabilitacyjne, zasiłek wyrównawczy oraz inne zasiłki przewidziane tą ustawą. Natomiast celem ubezpieczenia wypadkowego jest ochrona „wszystkich ubezpieczonych, którzy przy realizacji swojej aktywności zawodowej narażeni są na doznanie szkody na zdrowiu pozostającej w związku przyczynowym $\mathrm{z}$ tą aktywnością, przed skutkami trwałej albo czasowej niezdolności do pracy oraz zmniejszonej sprawności do pracy, będącej następstwem wypadku przy pracy, wypadku zrównanego z wypadkiem przy pracy i choroby zawodowej”. Ubezpieczenie wypadkowe chroni również ,uprawnione podmioty przed ekonomicznymi skutkami utraty żywiciela"21.

Ustawa z dnia 26 czerwca 1974 r. - Kodeks pracy ${ }^{22}$ reguluje kwestię wynagrodzenia za czas usprawiedliwionej nieobecności wskutek wypadku w drodze do pracy lub z pracy. Zgodnie z art. 92 \$ 1 i 2 k.p., za czas niezdolności do pracy spowodowanej wyżej wymienioną przesłanką trwającą łącznie 33 w ciągu roku kalendarzowego, a w przypadku pracownika, który ukończył 50. rok życia - trwającej łącznie do 14 dni w ciągu roku kalendarzowego - pracownik zachowuje prawo do $100 \%$ wynagrodzenia. W sytuacji wypadku w drodze do pracy lub z pracy, ubezpieczonemu przysługuje prawo do zasiłku chorobowego od pierwszego dnia ubezpieczenia, czyli zgodnie z art. 4 ust. 3 pkt 2 u.ś.p.u.s., wypadek $\mathrm{w}$ drodze do pracy lub $\mathrm{z}$ pracy wykluczony jest $\mathrm{z}$ tzw. okresu wyczekiwania, który wynosi 30 dni nieprzerwanego ubezpieczenia chorobowego - w przypadku, gdy podlega się obowiązkowo temu ubezpieczeniu, natomiast 90 dni nieprzerwanego ubezpieczenia chorobowego - w sytuacji, gdy jest to ubezpieczenie dobrowolne. Zastosowanie do wszystkich pracodawców sektora publicznego i prywatnego ma zasada, że niezdolność do pracy przez pierwsze 33 (14) dni w roku jest ryzykiem pracodawcy. Dłużej niż 33 (14) dni trwająca niezdolność do pracy jest ryzykiem instytucji ubezpieczeniowej - Zakładu Ubezpieczeń Społecznych, przy czym „suma tego ryzyka” zamyka się w tzw. okresie zasiłkowym, jest to czas, przez jaki pracownikowi przysługuje prawo do świadczenia pieniężnego $\mathrm{w}$ okresie niezdolności do pracy ${ }^{23}$. Zatem zasiłek chorobowy w związku z wypadkiem w drodze do pracy lub z pracy przysługuje ubezpieczonemu nie dłużej niż przez 182 dni i do tego okresu wlicza się niezdolność do pracy, w czasie której pracownik pobierał wynagrodzenie na podstawie art. 92 § 1 i 2 k.p. Zasiłek chorobowy w związku z wypadkiem $\mathrm{w}$ drodze do pracy lub z pracy wypłacany jest w wysokości 100\% podstawy wymiaru zasiłku (art. 11 ust. 2 pkt 3 u.ś.p.u.s.).

\footnotetext{
${ }^{20}$ G. Szybulska-Walczak, Ubezpieczenia społeczne, Warszawa 2015, s. 79.

${ }^{21}$ Ibidem, s. 93

${ }^{22}$ Ustawa z dnia 26.06.1974 r. Kodeks pracy, Dz.U. z 1998 r. Nr 21, poz. 94 ze zm.

${ }^{23}$ I. Jędrasik-Jankowska, op. cit., s. 219.
} 
Zasiłek chorobowy z ubezpieczenia wypadkowego również przysługuje od pierwszego dnia ubezpieczenia, jest on jak w przypadku zasiłku chorobowego z ubezpieczenia chorobowego, wykluczony z tzw. okresu wyczekiwania. Zasiłek chorobowy $\mathrm{z}$ ubezpieczenia wypadkowego przysługuje $\mathrm{w}$ wysokości $100 \%$ podstawy wymiaru. Okres pobierania zasiłku chorobowego z ubezpieczenia wypadkowego jest taki sam, jak w przypadku zasiłku chorobowego z ubezpieczenia chorobowego i wynosi 182 dni.

Po wykorzystaniu okresu zasiłku chorobowego w sytuacji wypadku w drodze do pracy lub z pracy, ubezpieczonemu przysługuje świadczenie rehabilitacyjne. Art. 18 ust. 1 u.ś.p.u.s. stanowi, że świadczenie rehabilitacyjne należy się ubezpieczonemu, który po wyczerpaniu zasiłku chorobowego jest nadal niezdolny do pracy, a dalsze leczenie lub rehabilitacja lecznicza rokują odzyskanie zdolności do pracy. Ubezpieczony ma prawo do świadczenia rehabilitacyjnego przez okres nieprzekraczający 12 miesięcy. Ustawodawca w art. 18 ust. 2 u.ś.p.u.s. reguluje tę kwestię zaznaczając, że świadczenie rehabilitacyjne przysługuje przez okres niezbędny do przywrócenia zdolności do pracy, a okres 12 miesięcy jest maksymalnym czasem przez jaki ubezpieczony może otrzymywać świadczenie rehabilitacyjne. Świadczenie to w przypadku wypadku w drodze do pracy lub z pracy przysługuje w wysokości $90 \%$ podstawy zasiłku chorobowego przez okres pierwszych 3 miesięcy, a $75 \%$ podstawy za pozostały okres.

Po wykorzystaniu okresu zasiłku chorobowego w przypadku wypadku przy pracy ubezpieczonemu również przysługuje świadczenie rehabilitacyjne. Różnica między świadczeniem rehabilitacyjnym w związku $\mathrm{z}$ wypadkiem $\mathrm{w}$ drodze do pracy lub z pracy a świadczeniem rehabilitacyjnym w związku z wypadkiem przy pracy, polega na wysokości podstawy wymiaru świadczenia. W sytuacji wypadku przy pracy, pracownikowi przysługuje przez cały okres pobierania tego świadczenia $100 \%$ podstawy wymiaru.

Zasiłek wyrównawczy przysługuje pracownikowi w związku z wypadkiem w drodze do pracy lub z pracy, który ma zmniejszoną sprawność do pracy, ale nie został uznany za osobę niezdolną do pracy. Pobieranie renty z tytułu niezdolności do pracy wyklucza stwierdzenie zmniejszonej sprawności do pracy. Zasiłek wyrównawczy przysługuje wyłącznie pracownikowi. Warunkiem jest wykonywanie pracy w ośrodku rehabilitacji zawodowej albo u pracodawcy na wyodrębnionym stanowisku pracy oraz osiąganie $\mathrm{z}$ tego powodu wynagrodzenia niższego od przeciętnego wynagrodzenia pracownika za okres ostatnich 12 miesięcy. Ubezpieczonemu pracownikowi, który uległ wypadkowi przy pracy i w związku z tym wynagrodzenie jego uległo obniżeniu wskutek stałego lub długotrwałego uszczerbku na zdrowiu, również przysługuje zasiłek wyrównawczy. 
Pozostałe świadczenia przysługują wyłącznie ubezpieczonemu, który uległ wypadkowi przy pracy i nie mają one zastosowania do ubezpieczonego, który uległ wypadkowi w drodze do pracy lub z pracy. Renta $\mathrm{z}$ tytułu niezdolności do pracy przysługuje ubezpieczonemu na podstawie art. 6 ust. 1 pkt 6 u.u.s.w.p., który stał się częściowo lub całkowicie niezdolny do pracy wskutek wypadku przy pracy. Wysokość renty nie może być niższa niż 120\% kwoty najniższej odpowiedniej renty ustalonej i podwyższonej zgodnie z ustawą o emeryturach i rentach z Funduszu Ubezpieczeń Społecznych. Z kolei renta szkoleniowa przysługuje ubezpieczonemu, któremu ze względu na niezdolność do pracy w dotychczasowym zawodzie, spowodowanej wypadkiem przy pracy, orzeczono celowość przekwalifikowania zawodowego (art. 6 ust. 1 pkt 7 u.u.s.w.p.). Ponadto zgodnie z art. 6 ust. 1 pkt 5 i art. 11 ust. 1 u.u.s.w.p., ubezpieczonemu, który uległ wypadkowi przy pracy i doznał stałego lub długotrwałego uszczerbku na zdrowiu przysługuje jednorazowe odszkodowanie. Wysokość tego odszkodowania to $20 \%$ przeciętnego wynagrodzenia, obowiązującego w dniu wydania decyzji, za każdy procent uszczerbku, zwiększone o 3,5-krotność przeciętnego wynagrodzenia, jeżeli została orzeczona całkowita niezdolność do pracy oraz niezdolność do samodzielnej egzystencji wskutek wypadku przy pracy.

Jednorazowe odszkodowanie dla członków rodziny zmarłego wskutek wypadku przy pracy przysługuje małżonkowi, wobec którego nie orzeczono separacji; dzieciom własnym i drugiego małżonka; dzieciom przysposobionym; przyjętym na wychowanie i utrzymanie przed osiągnięciem pełnoletniości wnukom; rodzeństwu i innym dzieciom; rodzicom, macosze, ojczymowi jeżeli w chwili śmierci ubezpieczonego prowadzili z nim wspólne gospodarstwo domowe oraz inne osoby wymienione w art. 13 ust. 1 i 2 u.u.s.w.p. W zależności od kręgu uprawnionych, zróżnicowana jest wysokość jednorazowego odszkodowania dla członków rodziny zmarłego wskutek wypadku przy pracy.

Renta rodzinna $\mathrm{z}$ ubezpieczenia wypadkowego przysługuje członkom rodziny zmarłego w okolicznościach wypadku przy pracy i zgodnie z u.u.s.w.p. nie może być niższa niż 120\% kwoty najniższej renty rodzinnej ustalonej i podwyższonej zgodnie z przepisami o emeryturach i rentach z Funduszu Ubezpieczeń Społecznych.

\section{Ochrona trwałości zatrudnienia}

Pracownikom niezdolnym do pracy wskutek zarówno wypadku w drodze do pracy lub z pracy, jak i wypadku przy pracy przysługuje ochrona trwałości zatrudnienia przed rozwiązaniem stosunku pracy. Gdy chodzi o pierwsze z wymienionych powyżej zdarzeń, pracodawca może rozwiązać umowę o pracę bez wypowiedzenia z przyczyn niezawinionych przez pracownika, na podstawie art. 53 § 1 k.p., gdy niezdolność pracownika do pracy trwa dłużej niż 3 miesiące, jeżeli pracownik był zatrudniony u danego pracodawcy krócej niż 6 miesięcy. 
Natomiast jeżeli pracownik był zatrudniony u danego pracodawcy co najmniej 6 miesięcy to pracodawca może rozwiązać umowę o pracę bez wypowiedzenia po wykorzystaniu 182 dni wynagrodzenia za czas choroby i zasiłku chorobowego. W przypadku, gdy pracownikowi przysługuje świadczenie rehabilitacyjne, pracodawca może rozwiązać umowę o pracę po pierwszych 3 miesiącach pobierania tego świadczenia. Łączny czas po jakim pracodawca może rozwiązać umowę o pracę bez wypowiedzenia z przyczyn niezawinionych przez pracownika wskutek długotrwałej niezdolności do pracy to 272 dni.

Natomiast w razie wypadku przy pracy pracodawca może rozwiązać umowę o pracę bez wypowiedzenia z przyczyn niezawinionych przez pracownika, jeżeli okres pobierania zasiłku chorobowego trwa dłużej niż 182 dni bez względu na to, jak długi był okres zatrudnienia tego pracownika. Jeżeli pracownikowi przysługuje świadczenie rehabilitacyjne to pracodawca może rozwiązać umowę o pracę na takich samych zasadach po upływie 3 miesięcy pobierania tego świadczenia. Zatem różnica w kwestii rozwiązania umowy o pracę bez wypowiedzenia z przyczyn niezawinionych przez pracownika polega na tym, że w sytuacji wypadku przy pracy nie ma znaczenia okres zatrudnienia u danego pracodawcy. Zatem również i tutaj zakres ochrony pracownika, który uległ wypadkowi przy pracy jest szerszy niż pracownika, który uległ wypadkowi w drodze do pracy lub z pracy.

\section{Podsumowanie}

Wcześniejsze regulacje prawne traktowały wypadek przy pracy i wypadek w drodze do pracy, i z pracy w taki sam sposób. Obecnie oba te wypadki podlegają pod inne ustawy i różnią się szeregiem świadczeń przyznawanych z tytułu owych zdarzeń. Kwalifikacja wypadku w drodze do pracy i z pracy jest o tyle krzywdząca, że gdyby nie konieczność wykonywania pracy i dojazdu do niej, to prawdopodobieństwo wystąpienia takiego wypadku byłoby znikome. Według mnie, jeden i drugi rodzaj wypadku jest w jakimś stopniu związany z pracą. Dlaczego zatem ustawodawca w nierówny sposób traktuje oba te wypadki? Z drugiej strony, udowodnienie przez pracodawcę, że wypadek nie był wypadkiem $\mathrm{w}$ drodze do pracy lub z pracy jest o wiele trudniejsze, gdyż ubezpieczony jest poza miejscem pracy i pracodawca nie jest $w$ stanie skontrolować czy wypadek miał rzeczywiście jakikolwiek związek z odbywaniem drogi. Pracownik może zeznać, że w drodze do pracy (po wyjściu z domu) złamał nogę przewracając się na chodniku, a w tak naprawdę mógł złamać nogę, ponieważ poślizgnął się, np. na wodzie wylanej w domu w kuchni. Mogłoby w takiej sytuacji dochodzić do wielu nadużyć. Pewnie i teraz dochodzi do wykorzystywania takiej sytuacji, natomiast świadczenia z tytułu wypadku w drodze do pracy lub z pracy są mniej atrakcyjne niż w przypadku wypadku przy pracy. Wypadek w drodze do pracy lub z pracy i tak traktowany jest przez ustawodawcę w szczególny sposób 
w stosunku do innych okoliczności chorobowych z ubezpieczenia chorobowego. Zasiłek chorobowy w tym przypadku przysługuje od pierwszego dnia ubezpieczenia chorobowego, a jego wysokość jest wyższa niż w innych sytuacjach. To przybliża wypadek w drodze do pracy lub z pracy do wypadku przy pracy. Jednakże wypadek przy pracy ma szerszy zakres świadczeń kompensacyjnych. Pracownikowi poszkodowanemu w wypadku przy pracy przysługuje świadczenie rehabilitacyjne w wysokości wyższej niż w sytuacji wypadku w drodze do pracy lub z pracy, oraz inne odszkodowania i renty z tytułu takiego wypadku. Moje wątpliwości, co do sprawiedliwości regulacji powoduje jednak fakt, że w sytuacji, gdy ubezpieczonemu przysługuje zasiłek chorobowy z więcej niż jednego tytułu, to w przypadku niezdolności do pracy w związku z wypadkiem przy pracy u jednego pracodawcy, ubezpieczonemu przysługuje zasiłek chorobowy z ubezpieczenia wypadkowego (100\%) z każdego z tych tytułów. Natomiast jeżeli ubezpieczony ulega wypadkowi w drodze do pracy lub z pracy do danego zakładu pracy, to tylko w przypadku tego jednego stosunku pracy ubezpieczony będzie miał prawo do $100 \%$ zasiłku chorobowego, a w kolejnym zakładzie pracy będzie pobierał zasiłek w wysokości $80 \%$ wynagrodzenia. Uważam, że w sytuacji, gdy ubezpieczonemu przysługują świadczenia z więcej niż jednego tytułu, to powinny przysługiwać one w takiej samej wysokości (bardziej korzystnej dla pracownika) z każdego z tych tytułów, bez względu na to czy to był wypadek przy pracy, czy wypadek w drodze do pracy lub z pracy.

\section{Bibliografia}

\section{Literatura}

Abramowski M., Postępowanie powypadkowe, Warszawa 2010.

Jachimowicz M., Wypadki przy pracy i choroby zawodowe. Świadczenia ubezpieczeniowe i cywilne, Warszawa 2013.

Jędrasik-Jankowska I., Pojęcia i konstrukcje prawne ubezpieczenia społecznego, Warszawa 2016. Szybulska-Walczak G., Ubezpieczenia spoteczne, Warszawa 2015.

\section{Akty prawne}

Uchwała Sądu Najwyższego z dnia 11 lutego 1963 r., III PO 15/62, OSNC 1963/10/215.

Ustawa z 26 czerwca 1974 r. Kodeks pracy, Dz.U. z 1998 r. Nr 21, poz. 94 ze zm.

Ustawa z dnia 12 czerwca 1975 r. o świadczeniach z tytułu wypadków przy pracy i chorób zawodowych, Dz.U. z 1983 r. Nr 30, poz. 144 ze zm.

Ustawa z dnia 13 października 1998 r. o systemie ubezpieczeń społecznych, Dz.U. z 1968 r. Nr 3, poz. 8 ze zm.

Ustawa z dnia 13 października 1998 r. o systemie ubezpieczeń społecznych, Dz.U. z 2015 r. poz. $121 \mathrm{ze} \mathrm{zm}$. 
Ustawa z dnia 25 czerwca 1999 r. o świadczeniach pieniężnych z ubezpieczenia społecznego w razie choroby i macierzyństwa, Dz.U. z 2014 r. poz. 159 ze zm.

Ustawa z dnia 30 października 2002 r. o ubezpieczeniu społecznym z tytułu wypadków przy pracy i chorób zawodowych, Dz.U. z 2015 r. poz. 1242 ze zm.

\section{Wyroki sądów}

Wyrok Sądu Apelacyjnego w Katowicach z dnia 26 czerwca 1997 r., III AUa 532/97, „Prawo Pracy" 1998/7/43.

Wyrok Sądu Apelacyjnego w Warszawie z dnia 13 kwietnia 2000 r., III AUa 1142/99, OSA 2001/3/10.

Wyrok Sądu Najwyższego z dnia 23 października 1980 r., III PRN 43/80, Lex nr 14558.

Wyrok Sądu Najwyższego z dnia 25 stycznia 1980 r., III URN 59/79, OSNC 1980/7-8/147.

Wyrok Sądu Najwyższego z dnia 31 stycznia 1973 r., III URN 38/72, OSP 1973/7-8/143.

Wyrok Sądu Najwyższego z dnia 4 października 2006 r., II UK 40/06, OSNP 2007/19-20/291.

Wyrok Sądu Najwyższego z dnia 7 marca 2006 r., I UK 127/05, Lex nr 299138.

Wyrok Trybunału Ubezpieczeń Społecznych z dnia 19 września 1958 r., TR III 149/1958, OSPiKA 1960, poz. 64. 